\title{
Planting designs and functional traits of native plant species used in restoration projects in araucaria forests
}

\author{
Modelos de plantios e atributos funcionais de espécies nativas utilizadas em \\ projetos de restauração em floresta de araucaria
}

\author{
Marluci Pozzan', Tanise Luisa Sausen ${ }^{\mathrm{II}}$ \\ Daniel Albeny Simões ${ }^{\mathrm{III}}$, Camila Kissmann ${ }^{\mathrm{IV}}$
}

\begin{abstract}
Araucaria forest (AF) is one of the most devastated vegetation types in the Atlantic Forest, with a high percentage of areas to be restored. The purpose of this study was to compare two planting models in areas of AF and to determine functional attributes of four native species for ecological restoration Schinus terebinthifolius, Psidium cattleianum, Eugenia involucrata, and Ocotea odorifera. The study compared the survival, initial growth, canopy cover, and ground cover throughout 18 months between systematic planting models (pioneer species interspaced with non-pioneer species in the same planting row) and random models (pioneer and non-pioneer species randomly distributed within the plots). The functional attributes assessed were average height growth, survival, susceptibility to frost, canopy diameter, and frequency of herbivory. There were no differences in survival, initial growth, and canopy cover of plants between the planting models. Schinus terebinthifolius presented $87 \%$ of the desirable attributes to use in restoration projects in AF with high rates of survival and growth (height growth and canopy diameter). The non-pioneer species had a survival rate of $50 \%$ or lower and are not recommended for joint planting with the pioneer species for implementation during the frost season in AF.
\end{abstract}

Keywords: Atlantic Forest; Ecological succession; Functional traits

\section{Resumo}

A Floresta com Araucária (FA) é uma das formações florestais da Mata Atlântica mais devastadas, com uma grande quantidade de áreas que precisam ser restauradas. Dessa maneira, a proposta deste estudo foi comparar dois modelos de plantio em áreas de FA e determinar atributos funcionais de quatro espécies nativas para restauração ecológica -Schinus terebinthifolius, Psidium cattleianum, Eugenia involucrata e Ocotea odorifera. Para isso, o estudo comparou sobrevivência, crescimento inicial, cobertura de copa e cobertura do solo por 18 meses entre o modelo de plantio sistemático (espécie pioneira intercalada com espécies não-pioneiras na mesma linha de plantio) e modelo sistemático (espécies pioneiras e não-pioneiras distribuídas aleatoriamente nas parcelas). Os atributos funcionais avaliados foram: crescimento médio em altura, sobrevivência, suscetibilidade à geada, diâmetro de copa e frequência de herbivoria. Não houve diferenças na sobrevivência, crescimento inicial e cobertura do solo entre os modelos de plantio. Schinus terebinthifolius apresentou $87 \%$ dos atributos desejáveis para uso em projetos de restauração na FA com altas taxas de sobrevivência e crescimento (crescimento em altura e diâmetro de copa). As espécies não pioneiras tiveram uma taxa de sobrevivência de $50 \%$ ou menos e não são recomendadas para o plantio conjunto com as espécies pioneiras com implementação durante a estação de geada em FA.

Palavras-chave: Mata Atlântica; Sucessão ecológica; Atributos funcionais

Engenheira Florestal, Ma., Proprietária da empresa Araçá Horta e Jardim, Rua Julio Romani, 144, CEP 89820-000, Xanxerê (SC), Brasil. marlucipozzan@gmail.com (ORCID: 0000-0002-1898-6731)

Bióloga, Dra., Professora e Pesquisadora do Laboratório de Ecologia e Sistemática Vegetal, Universidade Regional Integrada do Alto Uruguai e das Missões, CEP 99709-910, Erechim (RS), Brasil. tasausen@uricer.edu.br (ORCID: 0000-0001-9374-7485)

III Biólogo, Dr., Proprietário da empresa BioVectors, Rua Marechal Borman, 317-D, Sala 102, CEP 89801-050, Chapecó (SC), Brasil. danielalbeny@ gmail.com (ORCID: 0000-0002-8001-030X)

IV Bióloga, Dra., Pesquisadora Autônoma, Rua Marino Magro, 101-D, CEP 89809-462, Chapecó (SC), Brasil. camilakissmann@gmail.com (ORCID: 0000-0001-8636-4929) 


\section{Introduction}

The growing number of degraded areas in the Atlantic Forest biome demands the development of projects and studies that aim to preserve and restore biodiversity on a regional scale (CHAZDON, 2014), as is the case of Araucaria forest (AF). This forest formation features a mix of species of different origins from climate zones of high precipitation (OLIVEIRA-FILHO et al., 2015), and it requires actions of ecological restoration due to the significant reduction in its original coverage area (VIBRANS et al., 2011).

The planting of seedlings is the most commonly used restoration technique, because it speeds up the process of ecological succession and serves as a catalyst of natural regeneration (CHAZDON, 2014). In Atlantic Forest areas, the planting of seedlings has been adopted due to the high concentration of agricultural areas with deep levels of degradation (BRANCALION et al., 2012).

Since the end of the 1980s, the planting of seedlings using combinations of successional groups has been studied for the recovery of degraded areas (RODRIGUES; BRANCALION; ISERNHAGEN, 2009). The main techniques in active restoration are nucleation and seedling planting through filling and diversity lines (TRENTIN et al., 2018). Although nucleation has some advantages over the seedling planting through filling and diversity lines, as demonstrated in Trentin et al. (2018), the irregular spacing of nucleation plantings can present other challenges that may impact the cost of a project (CORBIN; HOLL, 2012). In addition, row planting offers other practical advantages such as fencing to reduce damage by herbivores and less chance of accidental damage during follow-up clearing to control ruderal vegetation (CORBIN; HOLL, 2012).

The main planting models used include the choice of species belonging to different successional groups and systematically distributed in plots-rows of pioneer species interspaced with rows of pioneer and non-pioneer species (TRENTIN et al., 2018), or rows with pioneer and non-pioneer species arranged alternately (RODRIGUES; BRANCALION; ISERNHAGEN, 2009). These planting models aim to quickly form canopy cover with the pioneer plants, creating favorable weather conditions for the development of species that belong to other stages of succession. There is less frequent description of planting models in which species of different successional groups are randomly distributed in rows in the area to be restored (KLIPPEL et al., 2015).

In addition to choosing the appropriate restoration technique, success depends on the selection of species to be used, which requires knowledge about their ecological and functional traits (CHAZDON, 2014). The functional traits include the morpho-physio-phenological traits of the organisms that influence their fitness (characterized by survival, growth, and reproduction) (PODGAISKI; MENDONÇA JUNIOR; PILLAR, 2011). Therefore, growth, canopy cover, and tolerance to frost are plant traits that can be used as indicators of the survival and development of species in restoration plantings, enabling the selection of those with better performance in a given habitat (PILON; DURIGAN, 2013).

In AF, geographical and climatic factors are determinant in the vegetation structure (SEVEGNANI et al., 2016), and the main environmental barrier for this vegetation type is the occurrence of rigorous frosts during the winter. Considering that mixed ombrophilous forest (MOF; another name for Araucaria forest) is distributed in high-altitude areas $(500-1,500 \mathrm{~m})$ subject to frequent frosts (SEVEGNANI et al., 2016), it is possible that the use of random planting leads to more severe damage by frost. However, no studies could be found in the literature that comparatively evaluate the effectiveness of the planting models used in AFs. This study is pioneering in this respect. Despite the intense degradation of AF (VIBRANS et al., 2011), few studies addressing restoration have been carried out for this physiognomy. One of them is a study of how the presence of pioneer species influences the establishment and growth of native and exotic species, with the aim of restoring AF (GANADE et al., 2011). 
Investigation of the efficacy of both the technique and the species chosen for the restoration projects is possible through the monitoring of areas submitted to restoration processes (RIGUEIRA; MARIANO-NETO, 2013). This enables adjustments and improvements to the projects and may highlight the need to adopt complementary measures to the implemented restoration project (BRANCALION et al., 2012). Considering all of the above, the goals of this study were $i$ ) to assess the survival and initial growth of seedlings in two planting models, and ii) to determine the functional traits of four native species of AF with potential use for restoration projects.

\section{Materials and methods}

\section{Study area}

The study was conducted at Mata Preta Ecological Station (ESEC), a federal conservation unit (from the Portuguese "Unidade de conservação" - UC) located in Abelardo Luz, Santa Catarina state, Brazil $\left(26^{\circ} 28^{\prime} 23.38^{\prime \prime} \mathrm{S} / 52^{\circ} 9^{\prime} 31.41^{\prime \prime} \mathrm{W}, 1026 \mathrm{~m}\right.$ of altitude) belonging to the AF vegetation type. The experimental area, in the northeastern part of the conservation unit (Figure 1), was used for agricultural cultivation for several years and was incorporated into the conservation unit in 2012. The experimental area is surrounded by a radius of $500 \mathrm{~m}$ of small forest fragments and areas destined to agriculture and livestock production. The soil of the area was covered by grass and a few regenerating trees until the moment the project was implemented.

Figure 1 - Location of Mata Preta Ecological Station, Santa Catarina state, Brazil

Figura 1 - Localização da Estação Ecológica da Mata Preta, Santa Catarina, Brasil

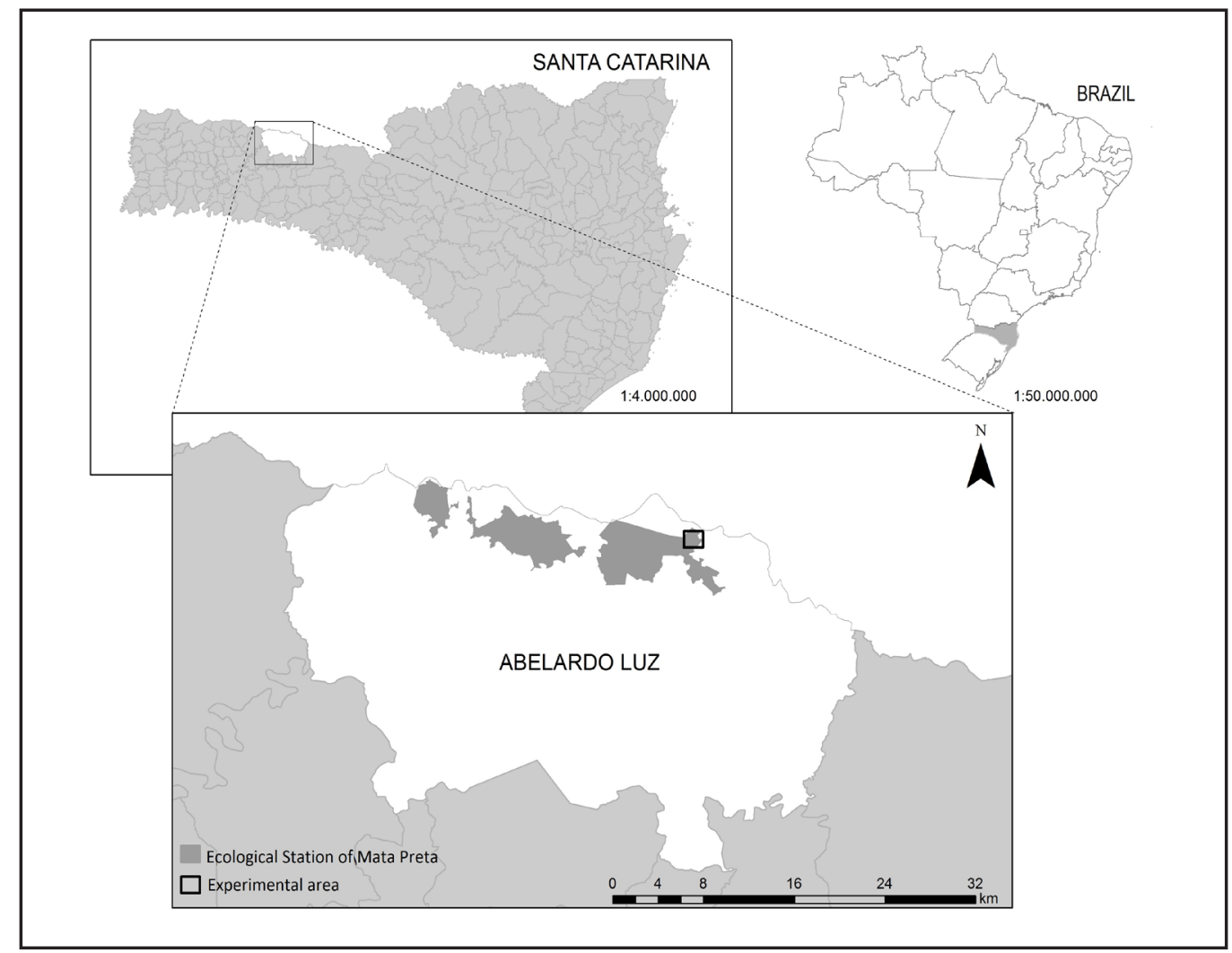

Source: Authors (2017) 
The climate in the area is $\mathrm{Cfb}$-oceanic climate with temperate summers, according to the Köppen classification (ALVARES et al., 2014). The data on precipitation, occurrence of frost, and minimum and maximum monthly temperatures during the months of the experiment (March 2015 to September 2016) were obtained from the Agronomic Institute of Paraná (IAPAR) station located in Palmas, Paraná state, $18 \mathrm{~km}$ from the experimental area (Figure 2).

Figure 2 - Precipitation, occurrence of frost, and maximum and minimum absolute monthly temperatures from March 2015 to September 2016 in Palmas, Paraná state, Brazil

Figura 2 - Precipitação, ocorrência de geada e temperaturas mensais absolutas máximas e mínimas de março de 2015 a setembro de 2016 em Palmas, Paraná, Brasil

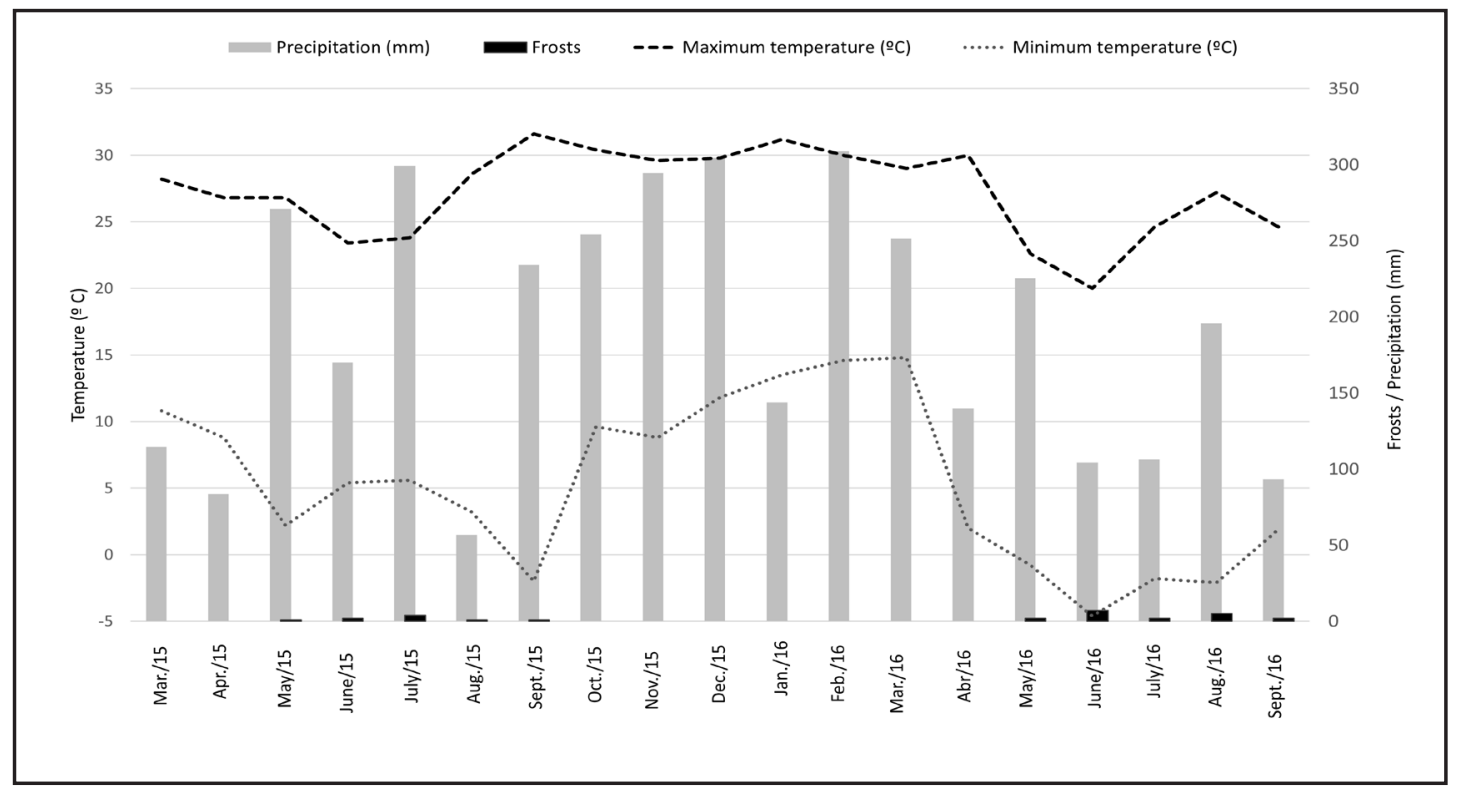

Source: Agronomic Institute of Paraná - IAPAR (2016)

Physical and chemical characteristics of the soil (Table 1) were analyzed in the surface layer $(0-20 \mathrm{~cm}$ of depth). The analyses were carried out in the laboratory of soil analysis at Empresa de Pesquisa Agropecuária e Extensão Rural de Santa Catarina (Epagri) in Chapecó (SC state).

Table 1 - Chemical and physical characteristics of the soil $(0-20 \mathrm{~cm}$ of depth $)$ of Mata Preta Ecological Station, Santa Catarina state, Brazil

Tabela 1 - Características químicas e físicas do solo (0-20 cm de profundidade) da Estação Ecológica da Mata Preta, Santa Catarina, Brasil

\begin{tabular}{|c|c|c|c|c|c|c|c|c|c|c|}
\hline \multicolumn{8}{|c|}{ Chemical Characteristics } & \multicolumn{3}{|c|}{ Physical Characteristics } \\
\hline \multirow{2}{*}{$\begin{array}{l}\mathrm{pH} \text { in } \\
\text { Water }\end{array}$} & \multirow{2}{*}{$\begin{array}{c}\text { Index } \\
\text { SMP }\end{array}$} & $\mathbf{P}$ & $\mathbf{K}$ & \multirow{2}{*}{$\begin{array}{c}\text { M. O. } \\
\%\end{array}$} & Al & $\mathrm{Ca}$ & $\mathrm{Mg}$ & Clay & Sand & Silt \\
\hline & & \multicolumn{2}{|c|}{$\mathrm{mg} / \mathrm{dm}^{3}$} & & \multicolumn{3}{|c|}{$\mathrm{cmol} / \mathrm{dm}^{3}$} & \multicolumn{3}{|c|}{$\%$} \\
\hline 5.0 & 5.9 & 3.8 & 44.0 & 3.9 & 1.6 & 3.0 & 1.9 & 62.6 & 6.9 & 30.5 \\
\hline
\end{tabular}

Source: Authors (2017) 


\section{Experimental design}

For each planting model (random and systematic), 10 plots (sampling units) of $54 \mathrm{~m}^{2}(9 \mathrm{~m} \mathrm{x} \mathrm{6m})$ were installed. The plots were systematically allocated, equally interspaced by $10 \mathrm{~m}$ gaps. Each plot had 16 seedlings planted, of which 8 were of pioneer species, 2 of early secondary species, 2 of late secondary species, and 4 of climax species, following the ratio of $50: 12.5: 12.5: 25 \%$ (pioneer : early secondary: late secondary: climax). The choice of species was based on the Flora Survey of the Araucarias National Park Management Plan (INSTITUTO CHICO MENDES DE CONSERVAÇÃO DA BIODIVERSIDADE, 2009), another conservation unit also located in the western region of Santa Catarina state, about 42 kilometers from the experimental area. Four species were used in the experiment, one representing each successional group (Table 2) (SILVA et al., 2012; TONETTO et al., 2013; SAUERESSIG, 2014). The criterion to choose the species, besides their occurrence, was the availability of seedlings in the nursery.

\section{Table 2 - Species and ecological classification of the seedlings used in the systematic and random plantings in Mata Preta Ecological Station, Santa Catarina state, Brazil}

Tabela 2 - Espécies e classificação ecológicas das mudas utilizadas nos plantios sistemático e aleatório na Estação Ecológica da Mata Preta, Santa Catarina, Brasil

\begin{tabular}{lccc}
\hline \multicolumn{1}{c}{ Species } & Common name & Family & SG \\
\hline Schinus terebinthifolius Raddi & Brazilian pepper tree (Aroeira vermelha) & Anacardiaceae & P \\
Psidium cattleianum Sabine & Strawberry guava (Araçá vermelho) & Myrtaceae & ES \\
Eugenia involucrata DC & Cherry of Rio Grande (Cereja do mato) & Myrtaceae & LS \\
Ocotea odorifera (Vell.) Rohwer & Brazilian sassafras (Canela sassafrás) & Laurareae & C \\
\hline
\end{tabular}

Source: Authors (2017)

Where: $S G$ = successional groups; $C$ = climax; $\mathrm{P}$ = pioneer; $\mathrm{ES}$ = early secondary; $\mathrm{LS}$ = late secondary.

The systematic planting followed the exact same sequence in all plots, alternating pioneer species with plants from the other groups, while in the random planting, the locations for each seedling within each plot were randomly determined. In both models, the seedlings were planted with spaces of $3 \times 2 \mathrm{~m}$ between them (RODRIGUES; BRANCALION; ISERNHAGEN, 2009).

\section{Installation of the experiment}

The installation of the experiment was carried out in March, 2015. The seedlings were produced in the native seedling nursery Jardim das Florestas, in Atalanta, Santa Catarina state. The site was prepared using mechanized mowing to reduce competition with the planted seedlings. Seedlings were planted manually into holes with $20 \mathrm{~cm}$ of depth (approximate height of the seedlings' root). The soil was not fertilized or irrigated during the planting process. After planting, the seedlings were marked with wooden sticks and identified with metal tags. The plants were not irrigated because it rained in the weeks after the planting process. Nine months after the planting, all the weeds and grass were removed in a radius of $0.5 \mathrm{~m}$ around each seedling.

\section{Data collection}

The survival, height, and diameter of seedlings planted were assessed at the moment of planting and then at $1,2,3,6,9,12,15$, and 18 months after planting (MAP). The mortality rate was calculated by the percentage of remaining seedlings in each assessment in relation to the initial number of seedlings planted. The height $(\mathrm{cm})$ was measured with a graduated ruler from the root collar to the terminal bud, and the diameter $(\mathrm{mm})$ was measured at $10 \mathrm{~cm}$ above ground with a digital caliper. 
Canopy cover and ground cover were assessed 18 months after the beginning of the experiment. Canopy cover was assessed using the line intercept method (RODRIGUES; BRANCALION; ISERNHAGEN, 2009). The line transects used to estimate cover were extended diagonally to the planting rows across each of the planting plots. Ground cover was estimated visually through the allocation of a subplot of $4 \mathrm{~m}^{2}(2 \times 2 \mathrm{~m})$ at the center of each plot. The proportion of soil covered by grass and herbaceous plants within each subplot was analyzed.

\section{Functional traits}

The selected functional traits were survival (S), susceptibility to frost (SF), average height growth (AHG), canopy diameter (CD), and susceptibility to herbivory $(\mathrm{H})$. In order to find the value of restoration (VR) for each species, three categories were established (Table 3); the category with the highest score corresponds to the best performance. The value of restoration for each species was calculated from the sum of the scores for each of the four traits converted into a scale of 0 to 100 using the rule of three (PILON; DURIGAN, 2013).

\section{Table 3 - Traits related to the performance of the species used in the planting of seedlings in restoration projects, and the score corresponding to each category}

Tabela 3 - Características relacionadas ao desempenho das espécies utilizadas no plantio de mudas em projetos de restauração e a pontuação correspondente a cada categoria

\begin{tabular}{|c|c|c|}
\hline Trait & Categories & Score \\
\hline \multirow{3}{*}{ Average height growth } & Less than $20 \mathrm{~cm}$ & 1 \\
\hline & 20 to $50 \mathrm{~cm}$ & 2 \\
\hline & More than $50 \mathrm{~cm}$ & 3 \\
\hline \multirow{3}{*}{ Canopy diameter } & Less than $20 \mathrm{~cm}$ & 1 \\
\hline & 20 to $40 \mathrm{~cm}$ & 2 \\
\hline & More than $40 \mathrm{~cm}$ & 3 \\
\hline \multirow{3}{*}{ Survival rate } & Less than $40 \%$ - Low & 1 \\
\hline & 40 to $60 \%$ - Intermediate & 2 \\
\hline & More than $60 \%$ - High & 3 \\
\hline \multirow{3}{*}{ Susceptibility to frost } & Death - High & 1 \\
\hline & Partial damage - Intermediate & 2 \\
\hline & No observable damage - Low & 3 \\
\hline \multirow{3}{*}{ Frequency of herbivory } & High (> 10\%) & 1 \\
\hline & Medium $(5-10 \%)$ & 2 \\
\hline & Low $(<5 \%)$ & 3 \\
\hline
\end{tabular}

Source: Pilon and Durigan (2013)

Susceptibility to frost was assessed at the end of June 2016, when there was a greater incidence of frosts at the location (Figure 2). The records were made using categories and each plant was included in one of the following categories: death, partial damage, or no observable damage. The category that most frequently occurred in each species was attributed to it. Canopy diameter, plant survival, and height growth were assessed at the end of the experiment (18 MAP). Susceptibility to herbivory was assessed 15 days after planting and then 6, 12, and 18 MAP. The frequency of herbivory was calculated using the Equation (1):

$\mathrm{Hbi}=100 \mathrm{hi}(\mathrm{ONi})^{-1}$

in which: $\mathrm{Hbi}$ = frequency of herbivory in species $\mathrm{i}(\%)$; $h \mathrm{i}=$ number of records of herbivory on individuals of the species $\mathrm{i}$ in all the observations made; $\mathrm{O}=$ number of occasions on which records of herbivory for the species i were made (4, in this study); $N i=$ total number of individuals of the species $i$. 


\section{Data analysis}

Data were analyzed using the free statistical software, $R$ ( $R$ DEVELOPMENT CORE TEAM, 2014). Plant survival was estimated using survival curves through the Kaplan-Meier estimator method. These curves were compared using the Log-rank test $(\mathrm{p}<0.05)$. In order to assess the effect of the planting model and of time on height and diameter growth of plants, a mixeddesign analysis of variance model (ANOVA) was used, with the planting plots and the plants being the fixed factors, and the planting models and the time being the random factors. In cases of a significant effect of any of the explanatory variables on the variation in response, the Tukey test $(\mathrm{p}$ $<0.05$ ) was later conducted to check the differences between the levels of the response variables. As the data regarding the height, diameter, and growth did not follow a normal distribution, they were logarithmized to enable the analyses. However, aiming for a better graphical effect, the figures used in this study were created using non-logarithmized values. The effect of the planting model on canopy cover and ground cover was analyzed using Student's t-test $(\mathrm{p}<0.05)$.

\section{Results and discussion}

\section{Planting models}

The survival curve of the species was similar in both planting models $(\mathrm{p}=0.972)$, with a recorded survival rate of $56.9 \%$ for the seedlings in random planting and $58.8 \%$ in systematic planting 18 MAP (Figure 3). The height growth of the seedlings (regardless of the species) was similar in both planting models, with gradual growth 6 MAP, corresponding to the assessments carried out in September. In the period from 15 to $18 \mathrm{MAP}$, which corresponded to the assessments carried out in winter, there was no observable variation in the height of seedlings (Table 4; Figure 4A).

Figure 3 - Survival curve of seedlings used in the systematic and random planting models in Mata Preta Ecological Station, Santa Catarina state, Brazil over 18 months after planting

Figura 3 - Curva de sobrevivência de mudas utilizadas nos modelos sistemático e aleatório de plantio na Estação Ecológica Mata Preta, Santa Catarina, Brasil, durante 18 meses após o plantio

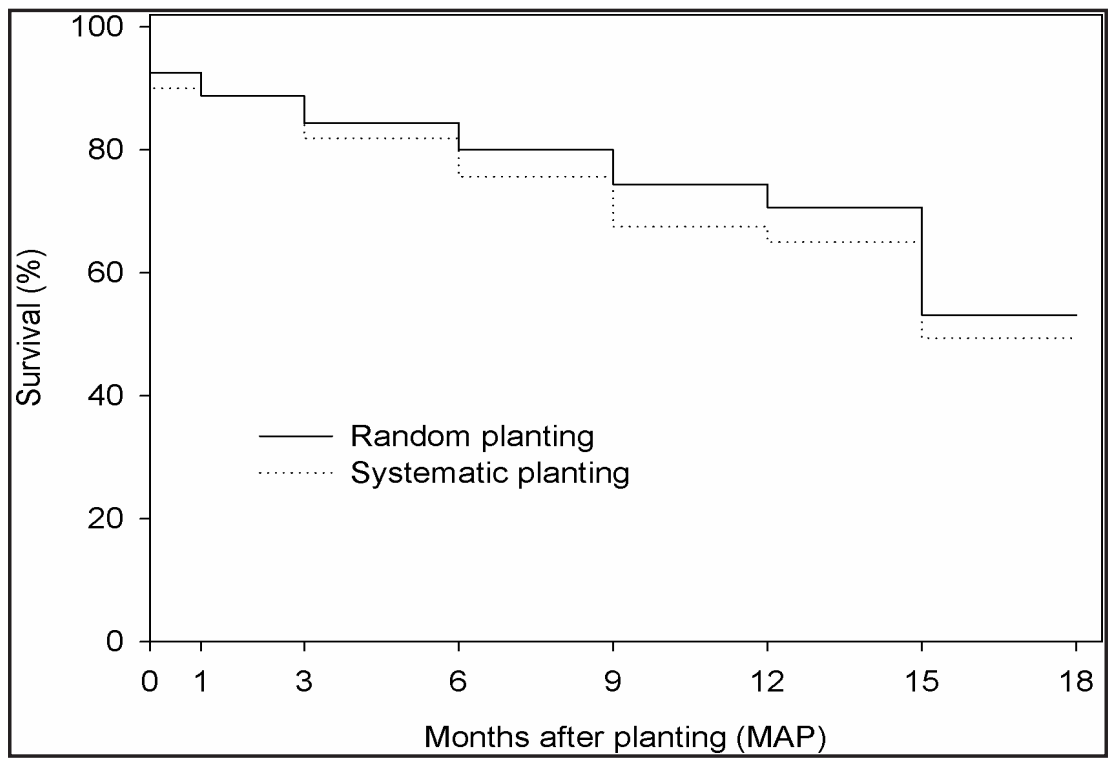

Source: Authors (2017) 
Table 4 - Variance analysis of the effect of the planting model and of time on the height and diameter of seedlings planted in Mata Preta Ecological Station, Santa Catarina state, Brazil

Tabela 4 - Análise de variância do efeito do modelo de plantio e do tempo na altura e diâmetro de mudas plantadas na Estação Ecológica da Mata Preta, Santa Catarina, Brasil

\begin{tabular}{|c|c|c|c|c|c|}
\hline \multirow{2}{*}{ Factor } & \multirow[b]{2}{*}{ G1 } & \multicolumn{2}{|c|}{ Height } & \multicolumn{2}{|c|}{ Diameter } \\
\hline & & $\mathbf{F}$ & $\mathbf{P}$ & F & $\mathbf{P}$ \\
\hline Planting model & 1 & 0.44 & 0.50 & 1.41 & 0.23 \\
\hline Time & 11 & 401.37 & $<0.001^{*}$ & 769.17 & $<0.001^{*}$ \\
\hline Planting model $\mathrm{x}$ Time & 11 & 0.73 & 0.73 & 2.55 & $<0.01^{*}$ \\
\hline
\end{tabular}

Source: Authors (2017)

Where: * indicates statistical difference between the averages $(\mathrm{p}<0.05)$.

The survival rate of seedlings 18 MAP in both planting models was close to $60 \%$, with the highest rate of mortality observed during the first year after planting. Seedling mortality is a highly important indicator that should be monitored from the implementation phase of restoration projects (1-12 months) up to 15 years or more after planting the seedlings, because a high mortality rate of seedlings may indicate the occurrence of competition with other plant species, grazing, predation, or allelopathy (BRANCALION et al., 2012; RIGUEIRA; MARIANONETO, 2013). There is no consensus in the literature about the acceptable level of mortality in reforestations in the Atlantic Forest, since the survival rates vary both in function of the species and the different vegetation types (CAMPOE; STAPE; MENDES, 2010), and in function of environmental variables (PALMA; LAURENCE, 2015).

Considering that the seedlings were planted in fall (March), it is likely that plant survival was influenced by the occurrence of frosts that were recorded from May to September, with a predominance in the months of June and July (Figure 2). There was an observable decrease in the survival rate of the species in the assessments carried out 3, 6, 15, and 18 MAP, which coincide with the period in which frosts were recorded in the area. The survival rate of seedlings in this study was similar to that found by Marcuzzo, Araújo and Gasperin (2015) in a reforestation in a deciduous seasonal forest, another vegetation type of the Atlantic Forest that is also subject to the occurrence of frosts in winter (MARCUZZO; ARAÚJO; GASPERIN, 2015).

Although frosts are one of the main selective factors for the establishment of seedlings in plantings in AF, there was also an observable mortality rate of seedlings in the initial planting period ( 15 days after planting) and in the assessments conducted 9 and 12 MAP, which corresponded to the months of December and March, in which there was no record of frost. However, precipitation is not the only factor that influences the survival of seedlings. The survival of seedlings in reforestation is influenced by the quality of the seedlings and by the forestry practices employed after the planting process (GROSSNICKLE, 2012). In seedling plantings carried out in areas that were used for agriculture, as was the case of the area used in this study, some measures should be taken during the first year: the area between the planting rows should be cleaned with herbicides, the seedlings should be crowned, leafcutter ants should be controlled, and ground cover should be fertilized (BRANCALION et al. 2012). However, these techniques increase the planting costs, and in this study it was only possible to clean the areas around the seedlings ("crowning").

For the diameter, there was an effect of time and an interaction between the factors (Table 4), with increased values from 6 up to $15 \mathrm{MAP}$, the period in which the seedlings of the systematic 
planting had a greater diameter (Figure 4B). Cleaning of the areas around the seedlings carried out 9 MAP resulted in height and diameter growth of the seedlings. This proves the negative effects of competition for environmental resources between weeds or invasive plants and the planted seedlings (RODRIGUES; BRANCALION; ISERNHAGEN, 2009). The gradual increase in height and diameter values recorded from November (9 MAP) to June (15 MAP) and the later stagnation of these values until September (18 MAP), show the influence of increased temperature and water availability on plant growth. These abiotic factors are typical growth boosters in tropical forests (SHIMAMOTO et al., 2016), and, although they were not the main factors associated with mortality, they can be considered the factors responsible for the stagnation in growth observed 18 MAP.

Figure 4 - Height (A) and diameter (B) of seedlings planted in Mata Preta Ecological Station, Santa Catarina state, Brazil. The points indicate the average values and the bars indicate the standard deviation. Different letters indicate a significant difference between the evaluation periods, and the symbol * indicates a difference between the planting models (Tukey, $\mathbf{p}<\mathbf{0 . 0 5}$ )

Figura 4 - Altura (A) e diâmetro (B) de mudas plantadas na Estação Ecológica Mata Preta, Santa Catarina, Brasil. Os pontos indicam os valores médios e as barras indicam o desvio padrão.

Letras diferentes indicam uma diferença significativa entre os períodos de avaliação e o símbolo * indica uma diferença entre os modelos de plantio (Tukey, $\mathrm{p}<0,05$ )

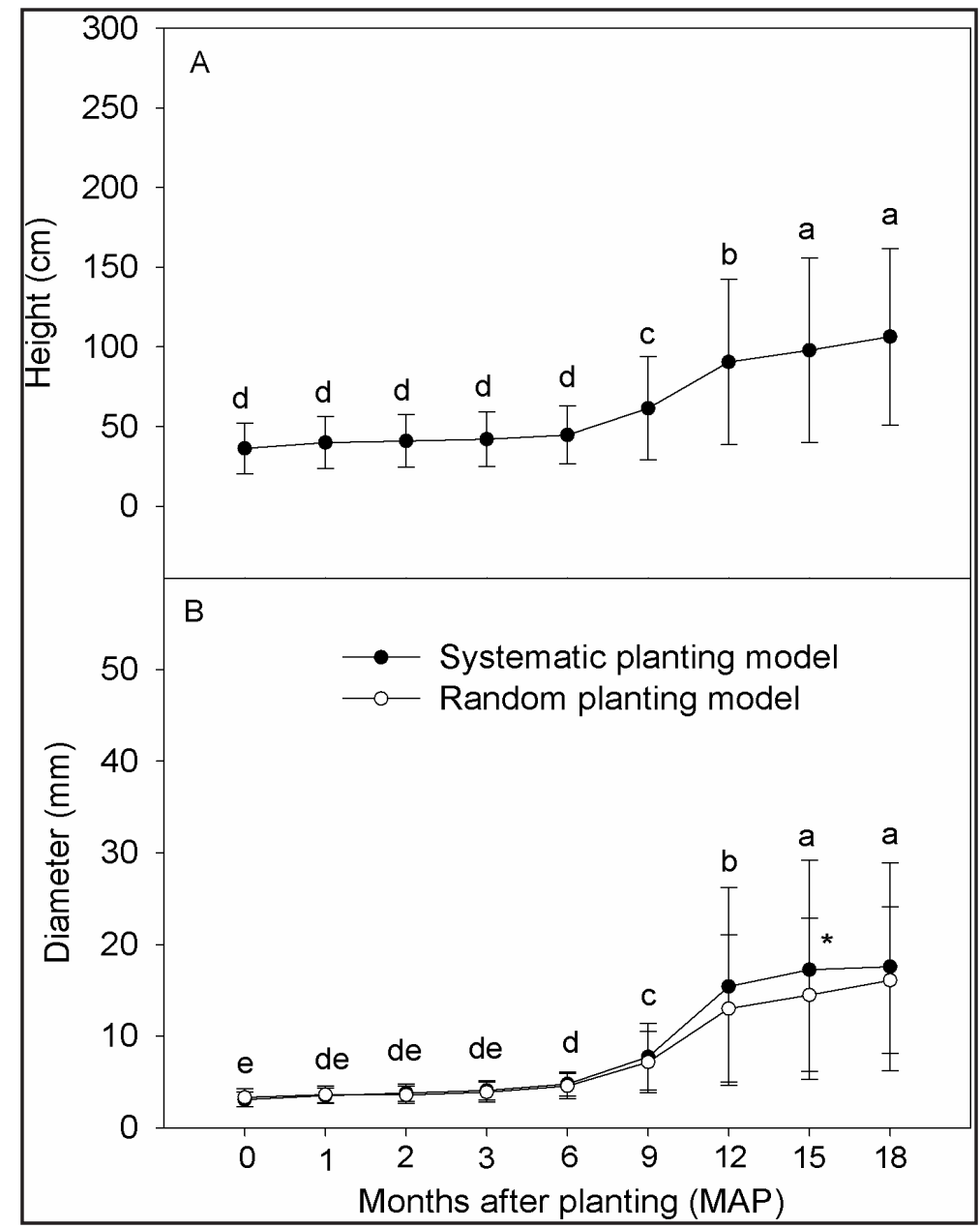

Source: Authors (2017) 
The canopy cover was similar in both planting models $(\mathrm{t}=1.8655, \mathrm{p}=0.07988)$ (Figure $5 \mathrm{~A}$ ), while the ground cover by grasses and herbaceous plants was higher in the random model $(\mathrm{t}=2.1973, \mathrm{p}<0.05)$ (Figure 5B). The assessment of canopy cover is a recommended indicator, especially for the first few years after planting, due to the influence of this parameter on the survival and growth of seedlings (DURIGAN; SUGANUMA; MELO, 2016). Besides creating the internal microhabitat of the forest, which favors the development of late species, the canopy formed by the pioneer species reduces the amount of light that reaches the ground, and consequently, the development of weed species (FIGUEIREDO et al., 2014). Thus, although there was no observable difference in canopy cover between the planting models, the higher values of this parameter observed in the systematic planting procedure resulted in less ground cover with grass in this plantation model, which suggests a possible advantage of the systematic plantation model in relation to the random model in the phases following the implementation phase (until 12 MAP) (LIMA et al., 2015).

Figure 5 - Canopy cover $(n=10)(A)$ and ground cover $(n=10)(B)$ in systematic and random seedling planting models in Mata Preta Ecological Station, Santa Catarina state, Brazil. Columns indicate the mean and bars indicate the standard deviation. Different letters indicate a significant difference between the treatments according to t-test $(\mathbf{p}<0.05)$

Figura 5 - Cobertura do dossel $(n=10)(A)$ e cobertura do solo $(n=10)(B)$ em modelos sistemáticos e aleatórios de plantio de mudas na Estação Ecológica Mata Preta, Santa Catarina,

Brasil. As colunas indicam a média e as barras indicam o desvio padrão. Letras diferentes indicam uma diferença significativa entre os tratamentos de acordo com o teste $t(p<0,05)$

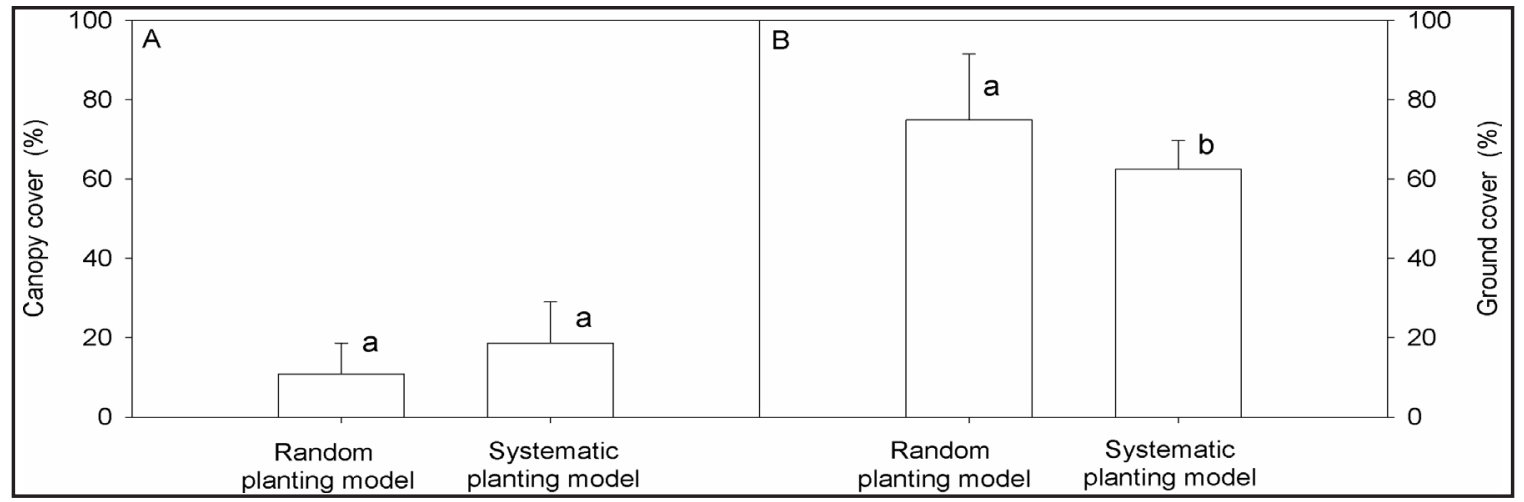

Source: Authors (2017)

\section{Functional traits}

Regarding the functional traits, the species showed distinct responses for each assessed functional trait (Table 5). Schinus terebinthifolius presented high values of S, AHG, and CD, and intermediate values of SF and $\mathrm{H}$, which resulted in the highest VR among the studied species. The secondary species Psdium cattleianum and Eugenia involucrata showed similar values for the assessed traits, except for SF and AHG. Psidium cattleianum had intermediate SF and Eugenia involucrata had a low SF. The AHG of Eugenia involucrata was more than twice that observed for Psidium cattleianum. Ocotea odorifera had low S, high SF, intermediate H, and AHG and CD lower than $20 \%$, resulting in the lowest VR among the studied species.

Based on the survival rate, growth (height and diameter of the canopy), tolerance to frost, and herbivory of the species studied, a value of restoration (VR - ranging from 0 to 100) for each species was assigned. The limited number of species in each category of ecological classification 
does not allow to make comparisons between the VR of the species, however, the determination of this value allows to identify the percentage of traits presented by Schinus terebinthifolius, Psidium cattleianum, Eugenia involucrata, and Ocotea odorifera in relation to the expected traits of species considered ideal for restoration $(\mathrm{VR}=100 \%)$. Furthermore, this present study is pioneering in the evaluation of species' functional traits with a focus on the restoration of the MOF, considering that in Brazil, only the Cerrado biome has been studied in a similar way (PILON; DURIGAN, 2013).

Table 5 - Classification of species by their traits related to their performance in restoration planting in Araucaria forest at Mata Preta Ecological Station, Santa Catarina state, Brazil

Tabela 5 - Classificação das espécies por suas características relacionadas ao seu desempenho em plantio de restauração em Floresta de Araucaria na Estação Ecológica de Mata Preta, Santa Catarina, Brasil

\begin{tabular}{lcccccc}
\hline \multicolumn{1}{c}{ Species } & S $(\%)$ & SF & AHG $(\mathbf{c m})^{*}$ & CD $(\mathbf{c m})^{*}$ & H & VR \\
\hline Schinus terebinthifolius & 79.5 & Intermediate & $82.6 \pm 43.0$ & $55.3 \pm 24.7$ & 7.50 & 87 \\
Psidium cattleianum & 50.0 & Intermediate & $4.5 \pm 11.0$ & $19.6 \pm 6.8$ & 5.00 & 53 \\
Eugenia involucrata & 45.0 & Low & $10.8 \pm 14^{*}$ & $17.8 \pm 6.7^{*}$ & 5.00 & 60 \\
Ocotea odorifera & 25.0 & High & $9.3 \pm 5.8^{*}$ & $18.6 \pm 3.2^{*}$ & 5.63 & 40 \\
\hline
\end{tabular}

Source: Authors (2017)

Where: $\mathrm{S}=$ Survival; $\mathrm{SF}=$ Susceptibility to frost $\mathrm{AHG}=$ Average height growth; $\mathrm{CD}=$ Canopy diameter; $\mathrm{H}=$ Frequency of herbivory; VR = Value of restoration (ranging from 0 to 100). * Mean \pm standard deviation.

Schinus terebinthifolius presented a value of restoration of 87 , which means that the species has $87 \%$ of the traits favorable to restoration. Indeed, this species displays morpho-anatomical and ecophysiological characteristics favorable to the occurrence in open areas, making it ideal to be used in restoration projects (RABELO et al., 2013). A survival rate close to $80 \%$ observed for the species of this study at 18 MAP corroborates the values found in other studies, such as that carried out by Sabbi, Ângelo and Boeger (2010), who recorded a survival rate of $73 \%$ at 18 MAP. The values of AHG and CD observed in this study are also similar to those observed for the species in restoration projects in deciduous seasonal forest (MARCUZZO; ARAÚJO; GASPERIN, 2015).

Although Psidium cattleianum is a species suitable for planting in full sun (LORENZI, 2014), it presented an AHG lower than other non-pioneer species and a mortality rate of $50 \%$ under the conditions of the present study. This fact may be related to the soil type, since the species develops best in moist soils (LORENZI, 2014).

The Eugenia involucrata species is also suitable for planting in open areas (TRENTIN et al.,2018), however it presented a survival rate less than $50 \%$ in the present study. Considering that the species presented a low SF, the high mortality rate may be related to local hydric and edaphic characteristics. According to Lorenzi (2014), the species requires well drained soils with high chemical fertility. In the present study, soil analysis presented a low to medium fertility (Table 1).

Ocotea odorifera is a species considered indispensable for restoration in areas of MOF and dense ombrophilous forest given its representativeness in the remainder of this vegetation (SILVA et al., 2012). However, in the present study, the plants of this species had low survival rates, possibly because it is a climax species and was planted along with other species. According to Silva et al. (2012), the planting of species should be carried out after canopy closure in the area. 


\section{Conclusion}

Among the species studied, only Schinus terebinthifolius is recommended for planting in AF in restoration projects interspaced by $3 \times 2 \mathrm{~m}$ gaps, planted in the fall, given its tolerance to frost. As non-pioneer species showed low survival rates ( $50 \%$ or less), partly due to the occurrence of frosts, and the fact that these species were planted along with pioneer species, they should be planted after canopy formation by pioneer species and during the spring/summer. Considering that the action of returning to the area to do the replanting increases the cost of restoration, plant densification in the MOF is an alternative that needs to be studied as a possible way to mitigate the damage caused by frost. Reduction of the space between the plants promotes a faster canopy closure, which protects non-pioneer species from climatic seasonality and optimizes their survival, as well as reduces the competition for light and nutrients with grass and herbs.

\section{Acknowledgements}

The authors thank ICMBio for authorizing this research, Unochapeco for supporting it, and Apremavi for donating the seedlings. Marluci Pozzan is grateful to CAPES for granting the master's degree scholarship.

\section{References}

ALVARES, A. A. e tal. Koppen's climate classification map for Brazil. Meteorologische Zeitschrift, [s. l.], v. 22, n. 6, p. 711-728, jan. 2014.

BRANCALION, P. H. S. etal. Avaliação e monitoramento de áreas em processo de restauração. In: MARTINS, S. V. (org.). Avaliação e monitoramento de áreas em processo de restauração. Viçosa, MG: UFV, 2012. p. 262293.

CAMPOE, O. C.; STAPE, J. L.; MENDES, J. C. T. Can intensive management accelerate the restoration of Brazil's Atlantic forests? Forest Ecology Management, [s. l.], v. 259, n. 9, p. 1808-1814, apr. 2010.

CHAZDON, R. Second growth: the promise of tropical forest regeneration in an age of deforestation. Chicago: University of Chicago Press, 2014.

CORBIN, J. D.; HOLL, K. D. Applied nucleation as a forest restoration strategy. Forest Ecology and Management, [s. l.], v. 265, p. 37-46, feb. 2012.

DURIGAN, G.; SUGANUMA, M. S.; MELO, A. C. G. Expected values for attributes of riparian forests undergoing restoration at different ages. Scientia Forestalis, Piracicaba, v. 44, n. 110, p. 463-474, jun. 2016.

FIGUEIREDO, P. H. A. et al. Germinação ex-situ do banco de sementes do solo de capoeira em restauração florestal espontânea a partir do manejo do sombreamento. Scientia Forestalis, Piracicaba, v. 42, n. 101, p. 6980, mar. 2014.

GANADE, G.etal. Pioneer effects on exotic and native tree colonizers: Insights for Araucaria forest restoration. Basic and Applied Ecology, [s. l.], v. 12, n. 8, p. 733-742, dec. 2011.

GROSSNICKLE, S. C. Why seedlings survive: influence of plant attributes. New Forests, [s. l.],n. 43, n. 5-6, p. 711-738, sep. 2012.

INSTITUTO AGRONÔMICO DO PARANÁ - IAPAR. Agrometeorologia. [s. l.], 2016. Available in: http:// www.iapar.br/modules/conteudo/conteudo.php?conteudo=2253. Acess in: 15 oct. 2016.

INSTITUTO CHICO MENDES DE CONSERVAÇÃO DA BIODIVERSIDADE. Plano de Manejo: Parque Nacional das Araucárias. [S. l.], 2009. Available in:

http://www.icmbio.gov.br/portal/unidadesdeconservacao/biomas-brasileiros/mata-atlantica/unidades-deconservacao-mata-atlantica/2199-parna-das-araucarias. Acess in: 20 oct. 2019. 
KLIPPEL, V. H. et al. Avaliação de métodos de restauração florestal de mata de Tabuleiros - ES. Revista Árvore, Viçosa, MG, v. 39, n. 1, p. 69-79, 2015.

LIMA, M. M. et al. Sobrevivência inicial de seis espécies usadas na recuperação de uma área degradada na Caatinga. Revista Ouricuri, Paulo Afonso, v. 5, n. 2, p. 132-137, jul./ago. 2015.

LORENZI, H. Árvores brasileiras: manual de identificação e cultivo de plantas arbóreas nativas do Brasil, 4. ed. Nova Odessa: Plantarum, 2014.

MARCUZZO, S. B.; ARAÚJO, M. M.; GASPARIN, E. Plantio de espécies nativas para restauração de áreas em unidades de conservação: um estudo de caso no sul do Brasil. Floresta, Curitiba, v. 45, n. 1, p. 129-140, jan./ mar. 2015.

OLIVEIRA-FILHO, A. T. et al. Delving into the variations in tree species composition and richness across South American subtropical Atlantic and Pampean forests. Journal of Plant Ecology, [s. l.], v. 8, n. 3, p. 242-260, jun. 2015.

PALMA, A. C.; LAURANCE, S. G. W. A review of the use of direct seeding and seedling plantings in restoration: what do we know and where should we go? Applied Vegetation Science, [s. l.], v. 18, n. 4, p. 561568, oct. 2015.

PILON, N. A.; DURIGAN, G. Criteria to indicate priority species for the restoration of cerrado vegetation. Scientia Forestalis, Piracicaba, v. 41, n. 99, p. 389-399, set. 2013.

PODGAISKI, L. R.; MENDONÇA JÚNIOR, M. S.; PILLAR, V. O uso de atributos funcionais de invertebrados terrestres na ecologia: o que, como e por quê? Oecologia Australis, [s. l.], v. 15, n. 4, p. 835-853, dez. 2011.

R DEVELOPMENT CORE TEAM. R: a language and environment for statistical computing. Vienna: R Foundation for Statistical Computing, 2014. Available in: http:/www.r-project.org/.

RABELO, G. R.et al. Structural and ecophysiological adaptations to forest gaps. Trees, [s. l.], v. 27, n. 1, p. 259272, fev. 2013.

RIGUEIRA, D. M. G.; MARIANO NETO, E. Monitoramento: uma proposta integrada para avaliação do sucesso em projetos de restauração ecológica em áreas florestais brasileiras. Revista Caititu, Salvador, v. 1, n. 1, p. 73-88, set. 2013.

RODRIGUES, R. R.; BRANCALION, P. H. S.; ISERNHAGEN, I. (org.). Pacto pela restauração da Mata Atlântica: referencial dos conceitos e ações de restauração florestal. São Paulo: LERF; ESAL̉Q; Instituto BioAtlântica, 2009.

SABBI, L. B. C.; ÂNGELO, A. C.; BOEGER, M. R. Influência da luminosidade nos aspectos morfoanatômicos e fisiológicos de folhas de Schinus terebinthifolius Raddi (Anacardiaceae) implantadas em duas áreas com diferentes graus de sucessão, nas margens do Reservatório Iraí, Paraná, Brasil. Iheringia, Porto Alegre, v. 65, n. 2, p. 171-181, dez. 2010.

SAUERESSIG, D. Plantas do Brasil - Árvores Nativas. 1st ed. Irati: Plantas do Brasil, 2014.

SEVEGNANI, L. et al. Climate affects the structure of mixed rain forest in southern sector of Atlantic domain in Brazil. Acta Oecologica, [s. l.], v. 77, p. 109-117, nov. 2016.

SHIMAMOTO, C. Y. et al. Stem growth rhythms in trees of a tropical rainforest in Southern Brazil. Trees, [s. l.], v. 30, n. 1, p. 99-111, feb. 2016.

SILVA, A. C. et al. Relações florísticas e fitossociologia de uma Floresta Ombrófila Mista Montana secundária em Lages, Santa Catarina. Ciência Florestal, Santa Maria, v. 22, n. 1, p. 193-206, jan./mar. 2012.

TONETTO, T. S. et al. Dinâmica Populacional e Produção de Sementes de Eugenia involucrata na Floresta Estacional Subtropical. Floresta e Ambiente, [s. l.], v. 20, n. 1, p. 62-69, jan./mar. 2013.

TRENTIN, B. E. et al. Restauração florestal na mata atlântica: passiva, nucleação e plantio de alta diversidade. Ciência Florestal, Santa Maria, v. 28, n. 1, p. 160-174, jan./mar. 2018.

VIBRANS, A. C. et al. Structure of mixed ombrophyllous forests with Araucaria angustifolia (Araucariaceae) under external stress in Southern Brazil. Revista de Biologia Tropical, [s. l.], v. 59, n. 3, p. 1371-1387, sep. 2011. 